\title{
DIE BEHANDELING VAN VIGS - GENEESMIDDELS EN VAKSIENE - WAT HOU DIE TOEKOMS IN?
}

\author{
C.J. van der Schyf \\ Departement Farmaseutiese Chemie \\ Potchefstroomse Universiteit vir $\mathrm{CHO}$ \\ POTCHEFSTROOM
}

\begin{abstract}
The developing epidemic of acquired immunodeficiency syndrome (AIDS) has prompled a broadly based research effort to find drugs and vaccines for preventing and treating this disease. Compounds such as zidovudine (AZT), ampligen and the broad spectrum of pyrimidine didenrynucleosides have yielded some promise for the tneatment of AIDS in terms of better quality of life for sufferers, but no cure is in sight yet. Also the quest for therapeutic and preventative vaccines has also been ongoing for several years. The latest development of the Salk vaccine has led to wild speculation in the lay press of a cure for AIDS. However, some seemingly insurmountable practical and moral-ethical problems beset both the development of AIDS chemotherapy and an AIDS vaccine. The most vexing of these problems is the lack of a suitable animal model for testing and the consequen questions of whether uninfected or HIV-infected but symtom-free volunteers can or should be used in testing potentially lethal compounds or vaccines.
\end{abstract}

\section{INILEIDING}

Slegs tien jaar gelede was die verworwe immuniteitsgebreksindroom (VIGS) 'n kliniese seldsaamheid wat slegs 'n handjievol individue met 'n unieke siektebeeld by geneeshere en hospitale laat aanmeld het. Twee jaar later is hierdie siekte beskryf as ernstig en sonder uitsondering, fataal. Die pasiënte was hoofsaaklik manlike homoseksuele en intraveneuse dwelmgebruikers en was hoofsaaklik beperk tot sekere metropolitaanse gebiede in die VSA. In 1985 sterf die bekende akteur Rock Hudson, en kort daarna die gewilde vermaaklikheidskunstenaar, Liberace, en skielik verskyn VIGS as die hoofopskrif van nasionale nuusblaaie. Sedertdien het die bekendheid van die siekte dit 'n alledaagse gespreksonderwerp gemaak en is baie kenners dit eens dat dit waarskynlik een van die mees katastrofiese siektes is wat nog ooit die mensdom bedreig het. Nog nooit voorheen is soveel van 'n enkele siekte geleer binne so 'n kort tydsverloop nie en nog nooit vonrheen is potensiële geneesmiddels teen ' $n$ vinniger tempo van die laboratorium tot die kliniek gebring nie. Selfs wetgewers in die VSA moes die knie buig teen druk van VIGS-lyers en geneeshere om groter kliniese toegang te verleen tot middels wat as bloot eksperimenteel beskou is (Seltzer, 1988:5 en Palca, 1989:19-21). 
Dieselfde dringendheid wat klinici sedertdien laat besin het, het gelei tot 'n breë front van navorsing wat die ontwerp en ontwikkeling van metodes om die siekte te voorkom of te behandel ten doel het.

Die ontdekking van die menslike immuungebrekveroorsakende virus (HIV = human immunodeficiency virus) as die veroorsakende faktor vir hierdie siekte (Gallo et al. 1984:449-451) het tot gevolg gehad dat terapie gerig kon word teen die organisme self. Sedertdien is ' $n$ hele aantal verbindings reeds ontwikkel wat klaarblyklik die replisering van HIV in vitro inhibeer. Die bekendste van hierdie verbindings, 3'-asido-2', 3'dideoksitimidien (ook asidotimidien, AZT of zidovudien genoem) het in kliniese proewe bewys gelewer dat die kliniese toestand van VIGS-lyers kan verbeter en die oorlewingstyd verleng kan word (Culliton, 1989:21-23). Hierdie reeks toetse met AZT was die eerste bewyse dat 'n gevestigde infeksie met enige patogeniese menslike retrovirus op antivirale terapie gereageer het en het die hoop laat opvlam dat daar ander, genesende behandeling vir VIGS moet wees.

Aangesien HIV-infeksie tot 'n groot mate voorkom kan word deur weerhouding van risikopraktyke, en voorkomende maatreesls breedvoerig in sommige van die meegaande artikels bespreek word, sal daar in hierdie oorsig slegs bespreking gevoer word oor die moontlikhede vir die ontwikkeling van chemoterapeutiese middels en vaksiene vir gebruik by die behandeling en voorkoming (deur vaksinering) van VIGS.

\section{STRATEGIEé VIR DIE BEHANDELING VAN VIGS}

\section{$2.1 \quad$ Antivirale terapie}

Vroeg reeds is daar aangetoon dat VIGS-pasiënte 'n wanbalans vertoon in twee basiese tipes immuunstelselselle, naamlik B-limfosiete en $\mathrm{T}$-limfosiete, met die verhouding van $B$-selle tot $\mathrm{T}$-selle wat baie verhoog is. Daar is intussen aangetoon dat hierdie wanbalans veroorsaak is deur drastiese uitputting van die T-selle. Natuurlikerwys het navorsers dus die T-selle ondersoek in hul soektog na die oorsaak van VIGS en is HIV gevind in 'n belangrike subgroep van T-selle, naamlik dié wat 'n antigeen uitdruk, genaamd T4 of CD4.

HIV is waarskynlik die mees komplekse retrovirus wat tot nog toe bestudeer is. Soos ander bekende dierretrovirusse bevat HIV gene wat die kernstruktuurproteïene (GAG-proteïene), die buitekapselglikoproteïene (ENV) en omgekeerde transkriptase, of virale DNA polimerase ( $\mathrm{POL}$ ) kodeer. Ook bevat dit sekwense aan beide terminale van die genoom, genoem die lang terminale herhalers (LTR = long terminal repeats) wat reguleringselemente bevat wat geassosieer is met die replikasie van die virus 
(Figuur 1). HIV is egter uitsonderlik deurdat dit vyf nie-strukturele gene bevat, naamlik tat-III, art/trs, 3'-orf, sar en $\mathbf{R}$, waarvan sommige belangrike reëlingsfunksies vervul wat lei na virale replisering (De Clercq, 1989:35-46). Juis hierdie kompleksiteit van die virus en sy lewensiklus, verskaf aan die ontwerper van anti-VIGS middels 'n verskeidenheid van potensiële teikens vir antivirale terapie, maar kompliseer eweneens die taak aansienlik (Yarchoan, Mitsuya en Broder, 1988:253-263).

Figuur 1. 'n Skematiese voorstelling van die geenstruktuur van HIV (volgens Yarchoan, Mitsuya en Broder, 1988:253).

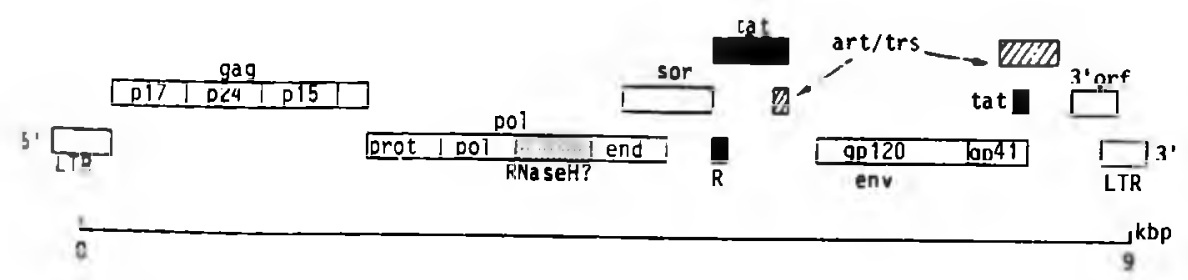

Die HIV-lewensiklus bied moontlike teikens vir antivirale terapie en sluit onder andere die volgende in:

i. Binding van die teikensel aan die CD4-reseptor.

ii. Samesmelting van die virus (wat waarskynlik verband hou met ENV gp41).

iii. Binnedringing van die teikensel.

iv. Dekapsulering van RNA.

v. $\quad$ Omgekeerde transkriptase (RNA $\rightarrow$ DNA, en dan DNA $\rightarrow$ DNA).

vi. Degradering van RNA deur RNase-aktiwiteit.

vii. Integrering van DNA in die gasheergenoom (deur integrase).

viii. Effektiewe transkripsie en translasie van RNA.

ix. Ribosomale leesraamverskuiwing.

$x$ Virale komponentproduksie en -samestelling.

xi. Virale afknotting.

xii. Infeksie deur selvrye virus. 
Om te reproduseer, moet die virus bind aan 'n gasheersel (via die CD4-reseptor), dit binnedring en dan dekapsuleer om sy RNA-genoom vry te stel. Deur sy eie omgekeerde transkriptase te gebruik, kan die virus 'n dubbelstring DNA-kopie van sy genoom produseer. Dié kopie word vervolgens geïntegreer in die gasheerselchromosoom en in RNA getranskribeer. Ná 'n komplekse reeks gebeure, word die nuwe RNA geënkapsuleer in 'n nuwe virale kapsel. Die virusdeeltjie kan vervolgens afknot van die gasheersel en voortgaan om 'n nuwe ligaamsel te besmet.

\subsubsection{Antivirale middels onder ontwikkeling vir gebruik teen VIGS}

Al bogenoemde prosesse word beheer deur die reeds genoemde gene van die HIV en bied teikens vir terapie. Só byvoorbeeld werk AZT en baie ander verbindings deur die replisering van die virus te belemmer. Die meganisme hiervoor is waarskynlik die gevolg van inmenging van die verbindings met omgekeerde transkriptase. Hierdie ensiem "bou" 'n DNA-kopie van die virale RNA-genoom deur gebruik te maak van timidientrifosfaat en ander nukleotiedboustene wat in die gasheersel gevind word. AZT kan hierdie proses termineer deurdat omgekeerde transkriptase AZT-trifosfaat verwar met timidientrifosfaat en dus die asido-(AZT)derivaat inkorporeer in die groeiende DNA-ketting. Wanneer die ensiem vervolgens probeer om die volgende nukleotied te heg, word dit gestuit deurdat die 3'-hidroksigroep wat vir hierdie proses noodsaaklik is en op timidientrifosfaat voorkom, ontbreek in die ingeboude "plaasvervangertimidien" (AZT). Die ketting termineer dus, en só ook virusreplisering.

Inhibering van virale binding bied ' $n$ interessante moontlikheid om die ontwikkeling van VIGS in 'n HIV-geïnfekteerde pasiënt teë te werk. 'n Gesolubiliseerde vorm van die CD4-reseptorglikoproteïen waarvan die sitoplasmiese en transmembraamgebiede ontbreek, kan HIV-binding en -replisering in teikenselle inhibeer. Kliniese proewe met hierdie middel word tans oorweeg (Yarchoan, Mitsuya en Broder, 1988:253-263). Ook dekstraansulfaat inhibeer HIV-replisering, waarskynlik gedeeltelik deur blokkering van die binding van die virus aan 'n teikensel (Ito et al., 1987:361-367). Ribavirien, 'n triasoolnukliosied vertoon ook antivirale aktiwiteit teen HIV. In 'n korttermyn kliniese toets (McCormick et al., 1984:1367-1369) het ribavirien HIV-replisering voorkom en die immuunstelsel verbeter. Dit is egter intussen aangetoon dat dit die aktiwiteit van AZT inhibeer (De Clercq, 1989:35-46).

Meer onlangse ontwikkelinge behels die bekendstelling van 'n reeks fosfonielmetoksietielpurienderivate, waarvan die prototipe (S)-HPMPA 'n breë spektrum van antivirale aktiwiteit het (De Clerq et al., 1986:464-467 en De Clercq et al., 1987:261-272) en waarskynlik deur die teikensel opgeneem en deur sellulêre ensieme na die aktiewe mono- en difosforielderivate omgeskakel word, asook 'n reeks verwante glikosilerings- 
inhibeerders soos kastanospermien en 1-deoksinojirimisien (Gruters et al., 1987:74-77 en Walker et al., 1987:8120-8124). Hierdie laaste ontwikkeling is interessant in dié sin dat die inhibering van glikosilering as 'n moontlike terapieroete geïdentifiseer is toe daar bepaal is dat die virale kapsel- gp 120-glikoproteilen wat betrokke is by die binding van HIV aan die CD4-reseptor, hoogs geglikosileerd is (31 tot 36 stikstofgekoppelde glikane per gp 120-molekuul). Daar is sedertdien aangetoon dat hierdie verbindings HIV-infektiwiteit verlaag en HIV-geïnduseerde sinsitiavorming (afknotting) inhibeer (Tyms et al., 1987:1025-1026).

Oorsigtelik word sommige van die interessante en meer resente ontwikkelings van verbindings wat nie alreeds bespreek is nie, met hul werkingswyse en moontlike voordele en newe-effekte in tabel 1 bespreek.

Tabel 1: 'n Seleksie van sommige van die nuutste geneesmiddelontwikkelings vir die behandeling van VIGS.

\begin{tabular}{ll}
\hline Middel & Opmerkings \\
\hline AL721 & $\begin{array}{l}\text { 'n Lipiedmengsel wat 'n mengsel van neutrale gliseriede, } \\
\text { fosfatidielchlolien en fosfatidieletanolamien bevat in } \\
\text { 'n 7:2:1-verhouding. Dit meng in met HIV infektiwiteit - } \\
\text { nie deur beweerde inhibering van omgekeerde transkripta- } \\
\text { se nie (Lachman, 1989:76) maar wel deur moontlike stabi- } \\
\text { lisering van die virusmembraan (Dagani, 1986:7-14). }\end{array}$ \\
\hline Ampligen & $\begin{array}{l}\text { 'n Verkeerdgepaarde dubbelstring RNA-polinukleotied } \\
\text { wat interferonvrystelling in die liggaam induseer } \\
\text { word tans klinies ondersoek en het oënskynlik minder } \\
\text { newe-effekte as 'n interferoninspuiting (Dagani, 1986: } \\
\text { 7-14; Yarchoan, Mitsuya en Broder, 1988:256). }\end{array}$ \\
\hline Ansamisien & $\begin{array}{l}\text { Antibakteriële middel en 'n rifamisienanaloog. 'n Mate } \\
\text { van effektiwiteit is verkry in VIGS-pasiënte met opportu- } \\
\text { nistiese Mycobacterium avium-intracellulare infeksie } \\
\text { (Lachman, 1989:78). }\end{array}$ \\
\hline
\end{tabular}


Die behandeling van VIGS - geneesmiddels en vaksiene.

\begin{tabular}{ll}
$\begin{array}{l}\text { Siklosporien } \\
\text { (Siklospo- } \\
\text { rien-A) }\end{array}$ & $\begin{array}{l}\text { 'n Sikliese oligopeptied met potente immuunonderdruk- } \\
\text { kende werking. Inhibeer die T4 limfosietafhanklike } \\
\text { immuunrespons. Twyfelagtige werking deurdat dit sg. } \\
\text { "geaktiveerde" T4-sell "deaktiveer", sodat HIV dit nie kan } \\
\text { infekteer nie. Baie erge newe-effekte (Dagani, 1986:8). }\end{array}$ \\
\hline $\begin{array}{l}\text { Foskarnet } \\
\text { (trinatrium- } \\
\text { fosfonoformaat) }\end{array}$ & $\begin{array}{l}\text { Inhibeer HIV omgekeerde transkriptase-aktiwiteit in vitro. } \\
\text { Formuleringsprobleme en erge newe-effekte is ontmoedi- } \\
\text { gend (Dagani, 1986:8), veral nierskade (Lachman, 1989: }\end{array}$ \\
\hline $\begin{array}{l}\text { HP). } \\
\text { (ammonium- }\end{array}$ & $\begin{array}{l}\text { Inhibeer omgekeerde transkriptase. Gebruik vir die be- } \\
\text { handeling van die akteur Rock Hudson. Geen terapeutie- } \\
\text { antimoniaat) }\end{array}$ \\
$\begin{array}{l}\text { se voordeel is nog gerapporteer nie en newe-effekte is on- } \\
\text { aanvaarbaar (Lachman, 1989:79). }\end{array}$ \\
\hline $\begin{array}{l}\text { a-Interferon } \\
\text { Glikoproteïen wat geproduseer word deur selle in reaksie } \\
\text { op virusinfeksie. Verbeter moontlik die immuunrespons. } \\
\text { Geen bewyse vir enige voordeel is tot nog toe gepubliseer } \\
\text { nie en die effektiwiteit is twyfelagtig (Lachman, 1989:84; }\end{array}$ \\
\begin{tabular}{l} 
Dagani, 1986:9). \\
\hline Suramin
\end{tabular} \\
$\begin{array}{l}\text { 'n Antiparasitiese geneesmiddel wat ook'n kragtige inhi- } \\
\text { beerder van virale omgekeerde transkriptase is. Dit het } \\
\text { baie erge newe-effekte en het min of geen verbetering te- } \\
\text { weeggebring in VIGS-pasiënte wat tot dusver op 'n gekon- } \\
\text { troleerde wyse behandel is nie (Broder } e \text { al., 1985:627). }\end{array}$ \\
\hline
\end{tabular}

\subsubsection{Effektiwiteit van die geneesmiddels wat tot dusver getoets is.}

Wetenskaplikes is nog onseker wat die virus aktiveer om uit sy latente fase (wat jare kan duur) te ontwaak en totdat die geheim opgelos is, is daar weinig hoop dat daar 'n middel ontwikkel sal word wat die virus sal uitskakel.

Die aantal verbindings wat tot dusver ontwikkel is in die stryd teen VIGS, is enersyds 'n aanduiding van die koorsagtige haas waarteen navorsing op die gebied plaasvind, maar andersyds 'n hartseer waarskuwing dat geen middel tot dusver kan aanspraak maak op die titel geneesmiddel nie. 
As gevolg van die feit dat daar nog geen effektiewe genesing vir die toestand is nie, het sommige navorsers hulle begin toespits op kombinasieterapie. Dit is reeds bekend (Ito et al., 1987:361-367) dat dekstraansulfaat, ampligen en $\alpha$-interferon 'n groter-asadditiewe aktiwiteit het wanneer dit in vitro in kombinasie met zidovudien (AZT) getoets word. Die denkrigting vir die toepassing van kombinasieterapie behels dat kleiner dosisse, met gevolglike verlaging van die individuele komponente se neweeffekte, maar met behoud of versterking van die anti-HIV aktiwiteit, daarin sal slaag om pasiënte wat HIV-geïnfekteer is se lewens te verleng, lewenskwaliteit te verbeter en moontlik ook hul vermoě om die virus aan ander oor te dra, te voorkom (Baum, 1990:24-26).

Groot verwagtings word gekoester vir die effektiwiteit van bogenoemde terapiebenadering. Aangesien die verbetering van lewensgehalte, en nie noodwendig lewensverlenging nie, die eerste prioriteit vir baie VIGS-lyers is, kan daar verwag word dat daar al groter druk geplaas sal word op hospitale en klinieke om hierdie eksperimentele middels aan VIGS-lyers beskikbaar te stel, met gevolglike onberekenbare druk op die finansiële reserwes van die staatsgesondheidskas.

2.1.3 Eties-morele struikelblokke in die pad van effektiewe anti-VIGS geneesmiddelontwikkeling

Aangesien reguleringsowerhede streng wetgewing toepas wat die toets van nuutontwikkelde farmakologies-aktiewe verbindings beheer, is dit vanselfsprekend dat die ontwikkeling van 'n potensiële nuwe geneesmiddel vir VIGS deur dieselfde proses sal moet gaan. As gevolg van die terminale aard van die siekte, is daar 'n aantal drukgroepe, veral uit die Amerikaanse homoseksuele bevolking, wat eis dat nuwe eksperimentele middels beskikbaar gestel word sodra produksie daarvan begin.

Die FDA (Food and Drug Administration) van die VSA - wat in daardie land die reguleringsfunksie vir geneesmiddeltoetsing vervul - verkeer onder al groter druk van groepe soos ACT NOW (AIDS Coalition to Network, Organize, and Win) en ACT UP (AIDS Coalition to Unleash Power), wat verskeje homoseksuele en ander VIGS-risikogroepe verteenwoordig, om beperkende maatreëls oor die toets van nuwe middels te skrap (Selzer, 1988:5).

Nieteenstaande simpatie vir die lyding van hierdie mense, is daar geweldige praktiese en etiese probleme om hierdie middels aan HIV-positiewe, maar nog simptoomlose pasiěnte, toe te dien. Aangesien die meeste van hierdie middels gevaarlik is uit hoofde van hul werkingsmeganisme (immuunonderdrukking, inmenging met DNA-replisering ens.) kan daar gevra word wie die verantwoordelikheid sal moet dra indien so ' 
pasiënt voortydig sterf of, erger nog, indien hy of sy, onder die indruk dat die terapie genesend is, voortgaan met seksuele en ander praktyke wat 'n gevaar vir ander kan inhou.

'n Verdere probleem met die toets van potensiële anti-HIV middels is die feit dat, om te bepaal of 'n bepaalde middel wel beskermende aktiwiteit het, dit vir 'n verlengde tydperk, soms 'n aantal jare, getoets en gemoniteer sal moet word (Dagani, 1986:10). HIV het die vermoë om latent in die gasheer te bly en eers na jare sy vernietigende effek op die immuunstelsel te begin uitoefen.

Terapietoetsing sal hiermee rekening moet hou en pasiënte wat met een middel behandel word, sal daarmee moet aanhou totdat die proef voltooi is en sou nie kon aanspraak maak op latere, moontlik meer effektiewe, nuwer behandeling nie.

'n Verdere morele vraagstuk is die kwessie van 'n kontrolegroep, dit wil sê 'n groep pasiënte wat nie behandeling ontvang nie en moet dien as ' $n$ verwysing ten opsigte van mortaliteit en morbiditeit teenoor die behandelde groep. Hoe eties regverdigbaar is dit om terapie - hoe gering die kans op sukses ook al mag wees - van iemand te weerhou wat in elk geval sal sterf? Wie neem die besluit ten opsigte van verdeling in kontrole- en proefgroepe? Sal daar enige vrywlligers wees vir die kontrolegroep of sal alle pasiënte aandring op "behandeling"?

Ten slotte kan 'n aanhaling uit die Helsinkiverklaring (wat etiese norme stel vir kliniese proewe op mense en diere) 'n sobere noot slaan: "... concern for the interests of the subject (lees: toetspersoon of pasiënt) must always prevail over the interests of science and society" (Lachman, 1989:116).

Tensy daar antwoorde op hierdie morele vraagstukke verkry kan word sal die uiteindelike droom van 'n geneesmiddel vir VIGS, waarskynlik nog verder die toekoms in, moontlik buite alle bereik, geskuif word .

\section{$2.2 \quad$ Vaksiene}

Met die verspreiding van VIGS en die kennis dat hierdie siektetoestand deur 'n patogeniese virus veroorsaak word, is 'n onmiddellike en logiese gevolgtrekking gemaak dat ook hierdie siektetoestand, soos die geval met pokke, masels en polio, onder beheer gebring kan word deur die ontwikkeling van 'n entstof (Francis, 1988: 1580).

HIV verander mettertyd in geïnfekteerde pasiënte deurdat vele nouverwante stamme 
oor 'n aantal jare ontwikkel en wat waarskynlik die gevolg van mutasies tydens die verloop van die siekte is (Kalish en Schlossman, 1985:112). Hierdie verskynsel het die implikasie dat ander virale eienskappe soos weefseltropisme of -spesifisiteit, repliseringstempo, weerstandigheid, virulensie, vatbaarheid vir anitivirale terapie en ander, ook mettertyd op 'n soortgelyke wyse kan verander, selfs in dieselfde persoon. Wat verder van belang is, is dat een individu klaarblyklik nie met meer as een stam HIV geïnfekteer raak nie, selfs onder toestande waar veelvuldige blootstelling onvermydelik was. Gevolglik wil dit lyk asof een of ander meganisme die herinfeksie van ' $n$ individu met ' $n$ ander stam voorkom. Die meganisme vir hierdie verskynsel is tans onbekend, maar een moontlikheid is dat teenliggaamproduksie as reaksie op 'n eerste infeksie beskerming verskaf teen opeenvolgende blootstellings. Indien hierdie teorie waar is, mag daar wel verwag word dat 'n vaksien teen HIV in die toekoms ontwikkel sal word (Zuchermann, 1988:86).

Met hierdie feite in gedagte het 'n groot aantal firmas, ten spyte van groot risiko's teen die sukses van sulke pogings, begin met die soektog na 'n VIGS-vaksien (Lachman, 1989:75). 'n Vaksien teen VIGS kan ontwikkel word op een van 'n aantal wyses waaronder die gebruik van 'n skadelose variant van HIV, geïnaktiveerde HIV of rekombinante vaksienproduksie uit virale proteïene of proteïenfraksies en ook inbouing van sekere HIV-gene in die vaksiniavirus in, op dieselfde prinsiep wat gevolg is met die pokkevaksien.

Die nuutste ontwikkeling is dié wat gekom het uit werk gedoen deur die poliovaksienpionier, Jonas Salk (Dagani, 1990:8). Hierdie vaksien is ontwikkel met geinaktiveerde HIV-deeltjies wat gedeeltelik gestroop is van hul kapselglikoproteïene (wat op sigself sitotoksies is vir gasheerselle). Daar word gehoop dat die geinnaktiveerde virus die immuunstelsel sodanig sal stimuleer dat dit in staat sal wees om die verdere verspreiding van die virus stop te sit. Daar is pas toestemming verleen vir die toets van hierdie vaksien in $60 \mathrm{HIV}$-seropositiewe pasiënte, wat geen teken van kliniese siekte het nie. Voorts word daar gesoek na 10 ongeïnfekteerde vrywilligers ouer as 65 jaar onder priesters en nonne in die Los Angeles-omgewing wat, as gevolg van hulle lae-risiko gedrag nie met HIV geïnfekteer sal wees nie (Dagani, 1990:8). Een groot probleem volgens sommige navorsers is dat die vaksien steeds lewensvatbare, infektiewe virusmateriaal mag bevat wat inenting dodelik sal maak vir die kontrolegroep.

Ten spyte van hierdie bemoedigende tekens, meen baie navorsers dat 'n vaksien vir die voorkoming van VIGS op die vroegste nie voor oor 10 jaar op die mark sal verskyn nie. 
Die behandeling van VIGS - geneesmiddels en vaksiene.

\subsubsection{Praktiese en etiese hindernisse op die pad na vaksienontwikkeling}

'n Aantal faktore soeel 'n rol by die stadige vordering wat gemaak is in die ontwikkeling van 'n VIGS-vaksien.

i. Alhoewel geïnfekteerde persone wel op 'n natuurlike wyse anti-liggame teen HIV produseer wat 'n mate van beskerming bied, is geen geval nog bekend waar die virus deur hierdie anti-liggame vernietig is nie.

ii. HIV mag binne in selle wat gevind word in bloed en semen die liggaam binnekom. Hierdie geïnfekteerde selle kan saamsmelt met T-limfosiete en daardeur die immuunsisteem ondermyn en nuwe virusproduserende selle vorm. Dit is te betwyfel of ' $n$ vaksien beskerming sal kan bied teen hierdie sel-tot-sel transmissieroete.

iii. HIV is geneties veranderlik en baie stamme is bekend. Dit kan aanvaar word dat baie meer onbekende stamme bestaan en elk verskil van die ander wat betref anti-liggaamproduserende proteïene (vergelykbaar met die situasie betreffende die griepvirus). Een vaksien sal dus onwaarskynlik beskerming bied teen al die stamme.

iv. Vaksiniavirusgeproduseerde vaksiene mag self ernstige infeksies veroorsaak in pasiënte wie se immuunstelsel alreeds onder druk verkeer (Zuchermann, 1988:86).

v. Lewende virusmateriaal mag gevaarlik wees as 'n vaksien. Geen persoon sal homself eties beskikbaar kan stel as 'n proefpersoon sodat 'n lewende virus, wat moontlik 'n dodelike siekte kan veroorsaak, op hom ingeënt kan word nie. Geen navorser sou eties-geregverdigde gronde kan aanvoer vir die uitvoer van só 'n eksperiment nie.

vi. In samehang met (v) hierbo, is daar geen plaasvervangerproefdier vir die toets van so 'n vaksien nie. VIGS is 'n siekte van mense en selfs analoë siektetoestande in sommige diere (bv. ape, katte ens.) word deur ander virusse veroorsaak en sou dus nie gebruik kon word in die plek van mense nie.

vii. Dooie HIV-virusdeeltjies is self ook potensieel gevaarlik as gevolg van die moontlikheid dat hulle kan regenereer en infeksie veroorsaak (Dagani, 1988:14).

viii. Die traagheid waarmee die siekte ontwikkel sal die bepaling van effektiwiteit asook veiligheid baie moeilik maak (Lachman, 1989:75).

ix. Dit is moeilik of selfs onmoontlik om vrywilligers te bekom vir die toets van vaksiene. Om 'n HIV-vaksien te toets, sou ongeïnfekteerde persone die bykans ondenkbare moet laat doen en hulle met HIV laat besmet sodat die effektiwiteit van die vaksien getoets kan word. Ook mag ander newe-effekte van sodanige vaksien vir gesonde, hoërisikovrywilligers onaanvaarbaar wees (Dagani, 1986:14). 


\section{TOEKOMSSKOUING - HOE GOU SAL VIGS GENEES OF DEUR VAKSINERING VOORKOM KAN WORD?}

In die lig van die gegewe inligting, is dit onmoontlik om 'n akkurate voorspelling te maak van wanneer, indien ooit, 'n geneesmiddel of vaksien teen VIGS gevind sal word.

Indien so 'n middel of vaksien vandag ontdek sou word, sou dit op grond van wetlike oorwegings nie voor oor ten minste vyf jaar die algemene mark kan bereik nie. As so 'n middel of vaksien $100 \%$ effektief sou wees, sou die bestaande groep geïnfekteerde persone oor vyf jaar al so groot wees dat 'n ramp nie afgeweer sou kon word nie. Gegewe daarby die koste-implikasies (al die ontwikkelde middels en vaksiene sal geweldig duur wees) en die logistiese probleme om die middels by pasiënte in afgeleë derdewêreldgebiede afgelewer en korrek toegedien te kry, kan aanvaar word dat daar in Afrika geen hoop gevestig moet word op die moontlike ontdekking van 'n kuur vir VIGS nie.

Tans is al antwoord opvoeding. Die beginsels van risikogedrag en voorkomende maatreëls moet by alle lae van die bevolking ingeskerp word. Die een (enigste?) positiewe aspek van VIGS is dat dit ' $n$ voorkombare siekte is. Die boodskap moet op elke moontlike wyse versprei word en verantwoordelikheid vir sy of haar eie gesondheid moet die eis van elke individu wees.

\section{BIBLIOGRAFIE}

BAUM, R.M. 1990. AAAS Symposium emphasizes progress made in AIDS research. Chemical and Enginecring News, 68(11):24.26.

BRODER, S., YARCHOAN,R., EN COLLINS, J.M. 1985. Effects of suramin in HTLV.III/LAV infection prescnting as Kaposi's sarcoma or AIDS-related complex: clinical pharmacology and suppression of virus replication in vivo. Lancet, 8456:627.

CULLITON, B.J. 1989. AZT reverses AIDS dementia in children. Science, 246:21-23.

DAGANI, R. 1986. Efforts intensify to develop drugs and vaccines that combat AIDS. Chemical and Engineering News, 64(49):7-14.

DAGANI, R. 1990. Further tests of Salk AIDS vaccine approved. Chemical and Engineering News. 68(12):8.

DE CLERCQ, E. 1989. Potential drugs for the treatment of AIDS. Joumal of Antimicrobial Chemotherapy, 23, Bylaag A:35-46.

DE CLERCQ, E., HOLY, A., ROSENBERG, I., SAKUMA, T., BALZARINI, J. \& MAUDGAL, P.C. 1986. A novel selective broad-spectrum anti-DNA virus agent. Nature, 323:464-467.

DE ClerCo, E., SAKUMA, T., BABA, M., PAUWEls, R., Bal.zarini, J. \& ROSENBERG, I. 1987. Antiviral activity of phosphonylmethoxyalkyl derivatives of purine and pyrimidines. Antiviral Research, 8:261-272.

FRANCIS, D.P. \& PETRICCIANI, J.C. 1985. The prospects for and pathways toward a vaccine for AIDS. New England Joumal of Medicine, 313(25):1586.

Koers $55(3) 1990: 317-328$ 
Die behandeling van VIGS - geneesmiddels en vaksiene.

GALLO, R.C., SALAHUDDIN, S.Z., POPOVIC, M., SHEARER, G.M., KAPLAN, M., HAYNES, B.F., PALKFR, T.J., RFDFIELD, R.R., OLESKE, J., SAFAI, B., WHITE, G., FOSTER, P. \& MARKHAM, P.D. Frequent detection and isolation of cytopathic ret oviruses (HTLV-III) Irom patients with AIDS. Science, 225:59-63.

GRUTERS, R.A NEEFJES, J.J., TERSMETTE, M., DE GOEDE, R.E.Y., TULP, A. \& HUISMAN, H.G. 1987. Interference with HIV-induced syncytium formation and viral infectivity by inhibitors of trim ming glucosidase. Nature, $330: 74-77$.

ITO, M AABA, M SATO, A PAUWELS, R, DE CLERCO, E. \& SHIGETA, $S$. 1987 Inhibitory effect of dextran sulphate and heparin on the replication of human immunodeficiency virus (HIV) in vitro. Antiviral Reseanch, 7:361-376.

KALISH, RS. \& SCHLOSSMAN, S.F. 1985. The T4 lymphocyte in AIDS. New England Joumal of Medicine, 312(2):112.

LACIIMAN, S.J. 1989 A second look at AIDS, the acquired immunodeficiency syndrome. An updated review with abstr acts of some of the relevant literature. Johannesburg : Lennon.

MCCORMICK, J R GETCHELL, I F MITCHELL, S.W, HICKS, D. R 1984. Ribavirin suppresses replication of lymphadenopathy associaled virus in cultures of human adult T-lymphocytes. Lancet, 2(8416) : 1367-1369

PALCA J. 1989. AIDS drug trails enter new age. Science, 246:19-21

SELZER, R. 1988. Protesters hit FDA for AIDS drug policies. Chemical and Engineering News, $\left(x_{i}(42): 5\right.$.

IYMS, A.S., BERRIE, E.M., RYDER, T.A, NASH, R.J., HEGARTY, M.P., TAYLOR, D.L. \& MOBBERLFY, MA 1987. Castanospermine and olher plant alkaloid inhibitors of glucosidase activity block the growth of HIV. Lancet, ii: 1025-1026

WAI.KER, B.D, KOWALSKI, M.W.C., KOZARSKY, K., KRIEGER, M. \& ROSEN, C. 1987. Intibition of human immunodefiency virus syncytium formation and virus replication by castanospermine. Procecdings of the Nalional Academy of Sciences of the United States of Amcrica, $84 \cdot 8120-8124$

YARCHOAN, R , MITSUYA, H \& BRODER, S. 1988. Therapeutic strategics in the treatment of AIDS. Annual Repons in Medicinal Chemistry, 23:253 263.

ZUCHERMANN, A J. 1988. Prospects for vaccines against HIV. British Medical Joumal, 297(6641):86. 